\title{
RESEARCH INTO PROPERTIES AND STRUCTURE OF BASIC POLYSACCHARIDE IN PRUNUS DOMESTICA (CHERRY)
}

\author{
Sh.Z. Tapdigov, N.A. Zeynalov, D.B. Taghiyev, U.M. Akhmedova, \\ A.I. Mammadova, M.Kh. Hasanova, M.A. Amirov \\ Acad. M. Nagiyev Institute of Catalysis and Inorganic Chemistry \\ National Academy of Sciences of Azerbaijan \\ H. Javid ave.113, Baku AZ1143, e-mail: shamo.chem.az@gmail.com
}

\begin{abstract}
The paper deals with FTIR and ${ }^{13} C N M R$ spectroscopic, thermo-gravimetric, radioactive and viscosimetric analyses of the diluted gum water solution. It revealed that there are galactan and arabinan in the basic residue of cherry gum extract in the environs of Shamakhi city (Azerbaijan) with $14 \%$ moisture mineral salts of 2-3\%. Most of them include e $\mathrm{Na}^{+}, \mathrm{Mg}^{2+}, \mathrm{Ca}^{2+}, \mathrm{K}^{+}, \mathrm{Zn}^{2+} \mathrm{Fe}^{3+}$ ions. In the meanwhile $\mathrm{Cu}^{2+}, \mathrm{Mg}^{2+}, \mathrm{Cd}^{2+}$ ions make up $0.001 \%$ of total mass. Following FTIR and $\mathrm{C} N M R$ analyses, there are mainly $-\mathrm{OH},-\mathrm{COOH},-\mathrm{O}$ - functional groups with molecular mass for arabinogalactan fraction of $130 \mathrm{kDa}$. At the same time, the quantity and activity of radioactive elements such as ${ }^{137} \mathrm{Cs},{ }^{226} \mathrm{Ra},{ }^{228} \mathrm{Ra},{ }^{40} \mathrm{~K},{ }^{235} \mathrm{U},{ }^{238} \mathrm{U}$ in the content of cherry gum have been established by $\gamma$-spectrometer method. It demonstrated that isotopes dominate in ${ }^{238} U$ and ${ }^{40} K$ and their activity are respectively $1.31 \pm 0.243$ and $04 \pm 0.16 \mathrm{Bk} / \mathrm{gr}$. The content of these radioactive isotopes in the gum makes it possible to produce arabinogalactan-based sorbents.
\end{abstract}

Keywords: polysaccharides, cherry gum, arabinogalactan, NMR and FTIR spectroscopy, radioactive isotope

\section{INTRODUCTION}

Over the past few years, new approaches to the production of therapeutical preparations based on immobilization of biologically active substances on polymer carriers have been developed [1-3]. Transportation of biologically active substances, including natural polyose and polyaminose extracted from the plants, has widely been used. Note that dextrane, starch, chitosan, cellulose, carboxymethylcellulose have no diaphragm properties as polymercarriers [4-6]. The arabinogalactan (AG) is increasingly used and offers ever growing promises among natural polyaminoses $[7,8]$. High-solubility and polyfunctionality of AG enables us to apply it in medicine and various spheres of biotechnology. AG is a biologically active natural polysaccharide, which displays gastro protective, diaphragm and immunomodulatory properties [9-11]. Note that the properties of $\mathrm{AG}$ mentioned above make it possible to use it as a carrier of medicine preparations, enzymes and microelements that are necessary for human organism. [12-15]

It should be added that complexes of AG with ions of copper, nickel, cobalt and iron with $60-80 \%$ yield have been synthesized. The amount of metal ions is $1-5 \%$ and it was established that AG is more perspective as a carrier of biogenic microelements. Complex of AG with iron ferrogal is widely used in medicine as preparations with anti-anemic and immunomodulatory properties [16-17].

$\mathrm{AG}$ is also used as polyose with antibacterial and antimutagenous effect and produced as Larex UF, Bio-Max, Clear Tac ${ }^{\mathrm{TM}}$ preparations. High dispersibility property enables us to use it as a supplement to food products (Hercules) and vitamin complexes [18-20].The authors analyze some vegetable gum exudates (plum tree, cherry tree) by means of FTIR and ${ }^{13} \mathrm{C}$ NMR spectroscopy, review thermo-gravimetric and rheological properties of aqueous solutions. Also, functional groups and main components of the 
analyzed gums have been identified, including galactan, xylan and arabinan. It emphasized that there are differences between the two gums in thermal stability. For the diluted aqueous solutions of the analyzed gums, Huggins constant values and intrinsic viscosity have been identified which are dependent on the structure, molecular weight and interactions between existing functional groups [21].

In the research works mentioned above, the use of AG obtained from different trees are shown. It is well known that species of plants growing in different climatic zones differ one from another by the content of cells and mechanism of processes. In this work, we have studied composition of gum extracted from cherry trees growing in Shamakhi region of Azerbaijan. The number and activity of some metal ions ( $\mathrm{Na}, \mathrm{Mg}, \mathrm{K}, \mathrm{Ca}, \mathrm{Zn}, \mathrm{Cu}, \mathrm{Mn}$, $\mathrm{Fe}, \mathrm{Pb}, \mathrm{Cd})$ and radioactive elements $(\mathrm{Cs}, \mathrm{Ra}$, $\mathrm{Ra}, \mathrm{U}, \mathrm{K})$ have been established in the composition of cherry gum. Characteristics of separated fractions; average molecular mass and amount of $-\mathrm{COOH}$ groups studied; their structures examined by FTIR and ${ }^{13} \mathrm{C}$ NMR spectroscopy method.

\section{EXPERIMENTAL PART}

\section{Materials}

The Prunus Domestica (cherry) gum species have been collected as tree exudates in the south-east of Azerbaijan, Shamakhi region
(Fig 1). After the collection, gums were dried at room temperature and powdered. AG was extracted from Prunus Domestica cherry gum through the use of relevant method [22].

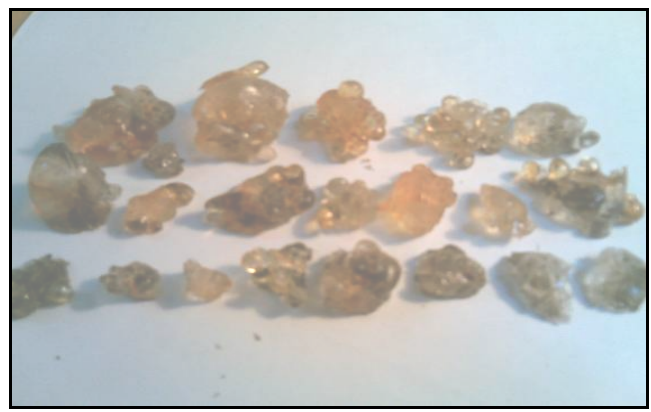

Figure 1. Raw polysaccharide samples from cherry tree, Prunus Domestica

It has to be kept in mind that $1 \mathrm{~kg}$ cold mass was thermo-stated in the water bath at 20 ${ }^{\circ} \mathrm{C}$ and separated solution extracted through filtering. Residual raw material was extracted twice by distilled water at $60-70{ }^{0} \mathrm{C}$ for 3 hours. The obtained solution was mixed, evaporated, and the raw material isolated by centrifuge, polysaccharide was precipitated in ethanol with $96 \%$ yield. The precipitate was dissolved in water and dialyzed and lyophilized in distilled water while raw AG was obtained with $5.8 \%$ yield. The glucuronic acid is used to determine the reaction with 3.5dimethylphenolom to take thick $\mathrm{H}_{2} \mathrm{SO}_{4}$ [23].

AAS analysis: $\mathrm{Na}, \mathrm{Mg}, \mathrm{K}, \mathrm{Ca}, \mathrm{Zn}, \mathrm{Cu}, \mathrm{Mn}$, $\mathrm{Fe}, \mathrm{Pb}$ and $\mathrm{Cd}$ metal ions were determined by flame atomic-adsorption method (AAS Spectra AA 220 FS, VARIAN).

Radioactive analysis: the amount and activity of radio-active elements were reviewed by means of $\gamma$-spectrometer HP and detected by Ge-detector with irradiation of samples for 3300 seconds.

Thermogravimetric analysis: Thermal characteristics of the cherry gum powder was determined by thermogravimetric-differential thermal analysis (TG-DTA, Diamond TG/DTA (PerkinElmer), in air at a heating rate of $0.167{ }^{\circ} \mathrm{C} / \mathrm{s}$. The analysis was run on $6 \mathrm{mg}$ sample for cherry, placed into a platinum crucible, under dynamic dry atmosphere (100 $\mathrm{mL} / \mathrm{min}$ ), at a heating rate of $10^{\circ} \mathrm{C} / \mathrm{min}$ within the $30-400{ }^{\circ} \mathrm{C}$ temperature range. 
${ }^{13}$ C NMR spectroscopy: The NMR spectrum was recorded in DRX-500 of «Bruker» (Germany) for 3-5\% solutions of olygo and polysaccharides with $\mathrm{D}_{2} \mathrm{O}$ at $303 \mathrm{~K}$ (internal standard is acetone, $\delta_{\mathrm{h}} 2.225 \mathrm{ppm}, \delta_{\mathrm{s}} 31.45$ ppm). Water solution was thickened in vacuum with rotative evaporator at 313-318 K within 10-20 minutes in the centrifuge with samples dried up.

FTIR spectroscopy: FTIR spectra of the plum and cherry gums were obtained by $\mathrm{KBr}$ pellet technique on ATR-FTIR Perkin Elmer instrument, Germany. Scans (32) were performed in the range of $400-4000 \mathrm{~cm}^{-1}$ with a resolution of $4 \mathrm{~cm}^{-1}$.

Viscosimetric characterization: Viscometric measurements were carried out using an Ubbelohde viscometer $\mathrm{V}_{2}, \quad(\alpha=0.5 ; \mathrm{K}=$ $\left.9.78 \times 10^{-4}\right)$ at $25 \pm 0.01{ }^{\circ} \mathrm{C}$. Several dilutions were made in situ.

\section{RESULTS AND DISCUSSION}

\section{AAS analysis}

According to initial view, AG collected from cherry trees is solid, fragile substance differently shaped, from light-beige to darkbrown colors, insoluble in high-soluble or colloid system to form alcohols and ethers. The gum sugar is refined from mechanical mixtures by filtering, and $1.0 \mathrm{~g}$ burns at 900 ${ }^{\circ} \mathrm{C}$. Note that $0.01405 \mathrm{~g}$ ash is processed with $0.1 \mathrm{~N} \mathrm{HNO}_{3}$ and all metal complexes take the form of $\mathrm{Me}_{\mathrm{x}}\left(\mathrm{NO}_{3}\right)_{y}$. The amount of metal ions in the solution is measured and the results are given in the table 1 .

Table 1. Mass and percentage of some metal ions at cherry gum.

\begin{tabular}{|c|c|c|c|c|c|c|c|c|}
\hline Ion of Me & $\mathrm{Na}^{+}$ & $\mathrm{Mg}^{2+}$ & $\mathrm{Ca}^{2+}$ & $\mathbf{K}^{+}$ & $\mathrm{Zn}^{2+}$ & $\mathrm{Cu}^{2+}$ & $\mathrm{Mn}^{2+}$ & $\mathrm{Fe}^{3+}$ \\
\hline Concentration, mg/l & 10.98 & 15.27 & 67.50 & 6.42 & 1.168 & 0.310 & 0.248 & 1.766 \\
\hline $\begin{array}{l}\text { Amount of metals in } \\
\text { cherry gum composition, } \\
\text { mg/g }\end{array}$ & 1.098 & 1.527 & 6.750 & 0.642 & 0.1168 & 0.0155 & 0.0124 & 0.0883 \\
\hline Мe, \% & 0.1098 & 0.1527 & 0.675 & 0.06 & 0.01 & 0.0015 & 0.0012 & 0.009 \\
\hline
\end{tabular}

As is known, gums are salts $\left(\mathrm{Ca}^{2+}, \mathrm{Mg}^{2+}, \mathrm{K}^{+}\right)$ with high molecular polysaccharides (glucuronic acid, galactouronic acid). Calcium salts occur more often than other salts. Cherry gum consists of $14 \%$ water and 2-3.5\% mineral substances [24]. Table 1 shows that cherry gum contains $1.2 \%$ metal ions. $\mathrm{AG}$ is a polysaccharide with linked structure which contains $4.7 \%$ glucuronic acid and $0.4 \%$ of free $-\mathrm{COOH}$ groups while

\section{Thermogravimetric analysis}

The thermal decomposition process for cherry gum can be observed: the first phase of decomposition occurs within 30-200 ${ }^{\circ} \mathrm{C}$ temperature range with a maximum degradation rate at $78{ }^{\circ} \mathrm{C}$ and mass loss of $12.8 \%$; the second phase (total mass loss is of $64.2 \%$ ) is noted for multiple decomposition the aqueous solution is noted for acidic character of $\mathrm{pH}=4 ; \mathrm{j} .66$.

A small amount of metal ions does not restrict the use of AG, on the contrary, metal ions in organism take part in various biochemical processes, and their presence in its composition is a positive result. It found that in case where metal ions are absorbed by polyose with $0.1 \mathrm{~N} \mathrm{HCl}$, no changes are observed in the activity of biological active compounds.

processes. Within the range of $200-272{ }^{\circ} \mathrm{C}$, the maximum rate occurs at $256{ }^{\circ} \mathrm{C}$ with mass loss of $32.6 \%$. Within the range of $272-$ $310{ }^{\circ} \mathrm{C}$, the maximum rate occurs at $284{ }^{\circ} \mathrm{C}$ with mass loss of $21 \%$. Within the range of $310-400{ }^{\circ} \mathrm{C}$, the maximum rate occurs at 338 ${ }^{\circ} \mathrm{C}$, with a mass loss of $17.6 \%$. 


\section{Radiactive analysis}

Thus, the research into cherry gumbased arabinogalactan shows that the amount and activity of some metal ions and radioactive elements have no negative impact on human organism [25].

In order to define the amount and activity of some radioactive elements in the composition of cherry gum purified from mechanical mixtures, $4 \mathrm{~g}$ gum sugar is dissolved in $100 \mathrm{ml}$ of deionized water. Then, spectrum of the sample is placed for 3300 seconds in $\gamma$-spectrometer (Fig. 2) and the amount and activity of some radioactive elements in the composition of gum sugar are given in Table 2. Table 2 shows that the amount and activity of radioactive elements are on the background level.

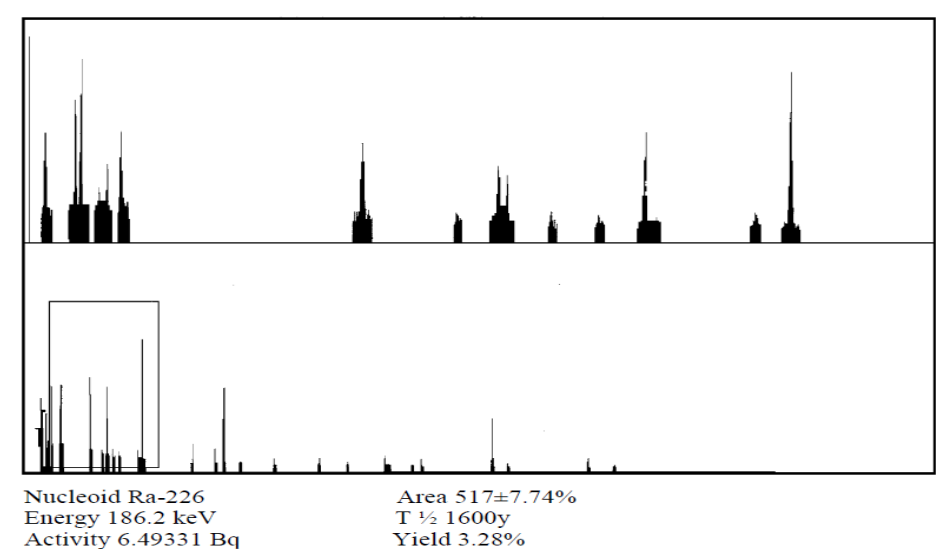

Figure 2. Radio-active elements spectra of cherry gum

Table 2. Amount and radioactive activity of some radionuclides in raw polysaccharide. $\mathrm{T}=20$ ${ }^{0}$ C. $\tau=3300$ second

\begin{tabular}{|c|c|c|c|c|c|c|}
\hline $\begin{array}{l}\text { Radioactive } \\
\text { elements }\end{array}$ & ${ }^{137} \mathrm{Cs}$ & ${ }^{226} \mathrm{Ra}$ & ${ }^{228} \mathrm{Ra}$ & ${ }^{235} \mathbf{U}$ & ${ }^{238} \mathbf{U}$ & ${ }^{40} \mathrm{~K}$ \\
\hline $\begin{array}{l}\text { Activity of } 4 \mathrm{~g} \text { gum in } 100 \mathrm{ml} \\
\text { solution, } \mathrm{Bk} / \mathrm{kg}\end{array}$ & $<0.39$ & $19.3 \pm 0.6$ & $3.8 \pm 0.3$ & $2.5 \pm 0.4$ & $52.2 \pm 9.6$ & $121.7 \pm 6.4$ \\
\hline $\begin{array}{l}\text { Amount of radioactive } \\
\text { elements in } 1 \mathrm{~g} \text { gum, } \mathrm{g}\end{array}$ & $<3.2 \cdot 10^{-15}$ & $13.1 \pm 0.55 \cdot 10^{-12}$ & $9.41 \pm 0.99 \cdot 10^{-15}$ & $788 \pm 20 \cdot 10^{-9}$ & $106 \pm 2 \cdot 10^{-6}$ & $11.7 \pm 0.6 \cdot 10^{-6}$ \\
\hline $\begin{array}{l}\text { Activity of radioactive } \\
\text { elements in } 1 \mathrm{~g} \\
\text { gum, } \mathrm{Bk} / \mathrm{g}\end{array}$ & $<0.01$ & $0.48 \pm 0.02$ & $0.095 \pm 0.01$ & $0.063 \pm 0.01$ & $1.31 \pm 0.24$ & $3.04 \pm 0.16$ \\
\hline
\end{tabular}

Note that the amount within the range of $10^{-6}-10^{-12} \mathrm{~g} / \mathrm{g}$ has no impact on physical-chemical properties of macromolecule.

\section{Viscosimetric characterization}

The characteristic viscosity of is 11194 (I) and 14423 (I), and the quantity precipitated and nonprecipitated fraction in of them in percent (for 1 gr mass) makes up ethyl alcohol (I) makes up [ $\eta]=1.15$ and [ $\eta] \quad 0.4$ and $0.312 \%$. Relatively high amount of $=0.97$ respectively. The fraction deposited in acidic groups in the fraction deposited in alcohol has a higher viscosity. Equivalent alcohol causes AG to be polyelectrolyte and amount of -COOH groups in polysaccharides expands its scope of application. According 
to characteristic viscosity values [26], the average molecular mass was determined for both fractions: both for I-precipitated fraction
$\mathrm{M}_{\mathrm{r}}=130 \mathrm{kDa}$ and II - nonprecipitated fraction it makes up $\mathrm{M}_{\eta}=98 \mathrm{kDa}$.

\section{${ }^{13}$ C NMR spectroscopy}

In previous studies, the methylation results show that the main chain in all highanalysis was conducted in line with Smith soluble arabinogalactan consists of $\beta$-Dand NMR spectroscopy studies. ${ }^{13} \mathrm{C}$ NMR $\quad(1 \rightarrow 3)$-Galp-units (Fig.3).

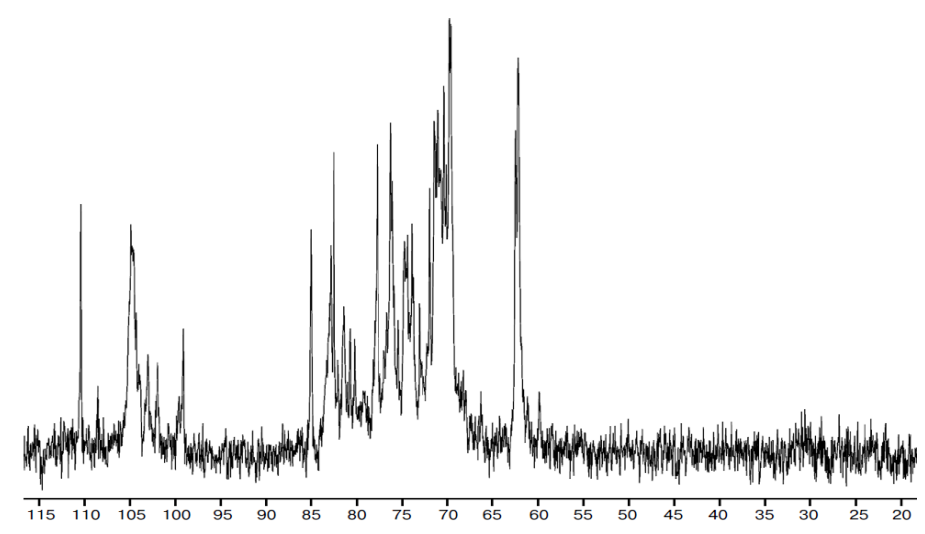

Figure 3. The ${ }^{13} \mathrm{C}$ NMR spectrum of water soluble AG from Prunus Domestica (Cherry) gum

The main chain consists of mainly $(1 \rightarrow 6)$-linked galactose, arabinose or glucuronic acid units. The ratios of the signals at $\delta=82.6 \mathrm{ppm}[\rightarrow 3,6)-\mathrm{Gal} p-(1 \rightarrow, \mathrm{C}-$ $3]$ and $\delta=62.3 \mathrm{ppm}[\beta-\mathrm{D}-\mathrm{Gal} p-(1 \rightarrow, \mathrm{C}-6]$ were used for the determination of the monomer unit ratio $\rightarrow 3,6)-$ Gal $p-(1 \rightarrow /$ Galp$(1 \rightarrow$. Owing to the signals (Fig. 3) at $\delta=102.6-106.1 \mathrm{ppm}$ the monomer unit ratio $\rightarrow 3, \quad 6)-\mathrm{Gal} p-(1 \rightarrow / \mathrm{Gal} p-(1 \rightarrow+\rightarrow 6)-\mathrm{Gal} p-$ $(1 \rightarrow$ can be determined [27].

\section{FTIR spectroscopy}

The FT-IR spectra of AG (Fig. 4) assigned to -COO groups (symmetric shows a peak at $2962 \mathrm{~cm}^{-1}$, which stretching). The intense peaks at $1071 \mathrm{~cm}^{-1}$ corresponds to $-\mathrm{CH}$ stretching of methyl and and $1042 \mathrm{~cm}^{-1}$ denote stretching of the C-Opropyl groups (symmetric, asymmetric). The $\mathrm{C}$ (valence vibration of uronic acids). peaks at $1654 \mathrm{~cm}^{-1}$ and $1538 \mathrm{~cm}^{-1}$ are

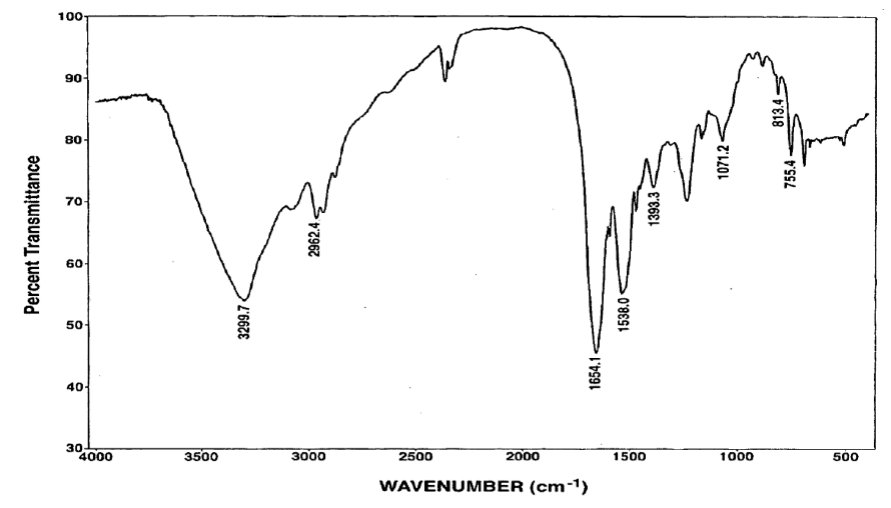

Figure 4. FTIR spectra of cherry gum 
The peak at $1420 \mathrm{~cm}^{-1}$ in the spectra of AG corresponds to the stretching vibration of $>\mathrm{C}=\mathrm{O}$ in $-\mathrm{COOH}$ functional group. The peak at $1393 \mathrm{~cm}^{-1}$ corresponds to the asymmetric stretch of $>\mathrm{C}=\mathrm{O}$. The absorption band of the $-\mathrm{OH}$ stretch of the -OH groups (stretching vibration) appears in the range of 3300-2700 $\mathrm{cm}^{-1}$. The FT-IR spectra confirm the functional groups content of AG [28].

The major structural conclusions (Fig.5) in this study are drawn from the ${ }^{13} \mathrm{C}$ NMR and FTIR spectroscopy analysis. In addition, the methylation analysis and the carbohydrate monomer composition provided some important structural features: e.g. the presence of unsubstituted $(1 \rightarrow 3)$-bonded Galp-units became apparent by the methylation analysis and the presence of GlcA in the Larch AG sample appeared from the carbohydrate monomer composition. Amounts of these units were probably under the limit of detection for the NMR analysis. Figure 5 shows a suggested average structure for water-soluble Shemakha cherry arabinogalactans.

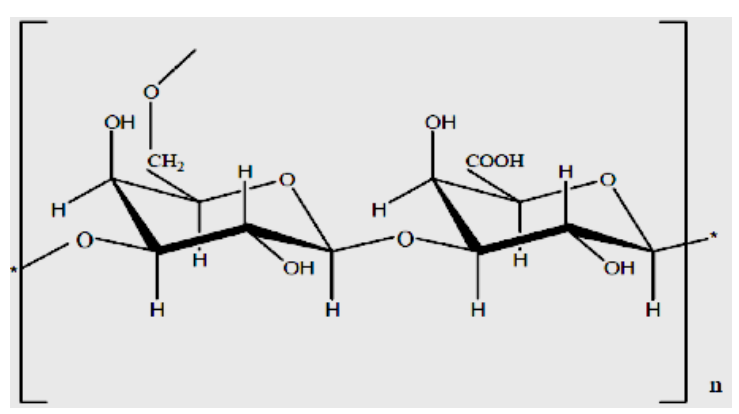

Figure 5. Suggested major structural features of typical arabinogalactan molecule

The structure slightly differs from molar masses and the mass range of these samples was quite broad. It is therefore unlikely that the different types of side chains will manifest themselves in a single molecule. However, a typical cherry arabinogalactan molecule has a shorter main chain than does a typical larch arabinogalactan molecule. It has also more free side units chains and a higher amount of acidic groups than larch arabinogalactan [29]. The low amount of $[\rightarrow 6)$-Galp- $(1 \rightarrow]$ units suggest that the probability of side chains with more than two units is very low. There are less acidic side chains and relatively high amount of $[\rightarrow 6)-\mathrm{Gal} p-(1 \rightarrow]$ units which suggest that the probability of side chains with more than two units is high. It was not possible to suggest the ratio of the three Galp-type side chains.

The sugar unit ratios of the isolated AG samples determined by acid methanolysis and methylation analyses, and ${ }^{13} \mathrm{C}$ NMR spectroscopy were in good agreement with each other. The Gal:Ara ratio for Shamakhi cherry AG determined by ${ }^{13} \mathrm{C}$ NMR proved to be high. This may be explained as being due to the unidentified signals from the anomeric carbons. Some polysaccharide fractions were lost during the isolation procedure.

\section{REFERENCES}

1. Manjanna K., Kumar T., Shivakumar B. Natural Exopolysaccharides. Novel Excipients in Drug Delivery. Archives of Applied Science Research. 2009, no. 1, pp. 230-253.
2. Mammadova S.M, Tapdigov Sh.Z., Humbatova S.F., Safaraliyeva S.F., Hasanova M.Kh., Zeynalov N.A. Research into Hydrogel Swelling Capacity on the Basis of Polyacrylic Acid and İmmobilization of Doxorubicin Thereupon. 
Kimya Problemleri - Chemical Problems. 2016, no. 4, pp. 377-386. (In Azerbaijan).

3. Hoffman A.S. Hydrogels for biomedical applications. Advanced Drug Delivery Reviews. 2012, vol. 64, pp. 18-23.

4. Rosu A., Bistriceanu S., Ibanescu C. et al. Rheological research of some polysaccharide gels loaded with Nigella Sativa extracts. Cellulose Chemistry And Technology. 2013, vol. 47, p. 359.

5. Liu Li, Gao Qi, Lu Xuemin et al. In situ forming hydrogels based on chitosan for drug delivery and tissue regeneration. Asian J. of Pharmaceutical Sciences. 2016, no. 11, pp. 673-683.

6. Schacht E.H. Polymer chemistry and hydrogel systems. J.Physics:Conference Series. 2004, no. 3, pp.22-28.

7. Anderson C.T., Carroll A., Akhmetova L.et al. Real-time imaging of cellulose reorientation during cell wall expansion in Arabidopsis roots. Plant Physiology. 2010, vol. 152, pp. 787-796.

8. Coviello T., Matricardi P., Marianecci C. et al. Polysaccharide hydrogels for modified release formulations. J. Control Release. 2007, vol. 14, pp. 5-24.

9. Shemshadi R., Zeynalov N.A., Tapdiqov Sh.Z.et al. Removal of Cadmium (II) by Natural Absorbents. Kimya Problemleri Chemical Problems, 2009, no. 3, pp. 586589. (In Azerbaijan).

10. Ahmadi R., Kalbasi-Ashtari A., Oromiehie A. et al. Development and characterization of a novel biodegradable edible film obtained from psyllium seed (Plantago ovata Forsk). J. of Food Engineering. 2012, vol. 109, pp.745-751.

11. Prabaharan M, Mano JF. StimuliResponsive Hydrogels Based on Polysaccharides Incorporated with ThermoResponsive Polymers as Novel Biomaterials. Macromol Biosci. 2006, vol. 6, pp.991-1008. 12. Bitencourt C.M., Trindade C.S.F., Sobral P.J.A.et al. Gelatin based films additivated with curcuma ethanol extract: Antioxidant activity and physical properties of. Food Hydrocolloids. 2014, vol. 40, pp.145-152.

13. Tapdiqov Sh.Z., Zeynalov N.A., Humbatova S.F. et al. Content of arabinogalactan from cherry gum (prunus avium) and as a polymer carrier for immobilization of trypsin. Asian J. of Chemistry. 2016, vol. 27, pp. 189-193.

14. Cascone M.G., Barbani N., Giusti P. et al. Bioartificial polymeric materials based on polysaccharides. J.Biomaterials Science. 2001, no.12, p. 267.

15. Tapdiqov Sh.Z., Zeynalov N.A., Taghiyev D.B. et al. Hydrogels for Immobilization of Trypsine Based on Poly$\mathrm{N}$-vinypyrrolidone and Arabinogalactan Graft Copolymers. J.Chem.Soc.of Pakistan. 2015, no. 12, pp. 1112-1118.

16. Mucalo M.R., Bullen C.R., ManleyHarris M. et al. Arabinogalactan from the Western larch tree: A new, purified and highly water-soluble polysaccharide-based protecting agent for maintaining precious metal nanoparticles in colloidal suspension. J.Materials Sciences. 2002, vol. 37, p. 493.

17. Robinson R.R., Feirtag J., Slavin J.L. Effects of dietary arabinogalactan on gastrointestinal and blood parameters in healthy human subjects. J.American College of Nutrition. 2001, vol. 20, p. 279.

18. Fitzpatrick A., Roberts A., Witherly S. Larch arabinogalactan: a novel and multifunctional natural product. Agro Food Ind Hi-Tech. 2004, vol.15(1), p.30-32.

19. Currier N.L., Lejtenyi D., Miller S.C. Effect over time of in-vivo administration of the polysaccharide arabinogalactan on immune and hemopoietic cell lineages in murine spleen and bone marrow. Phytomedicine. 2003, no. 10, pp. 145-153.

20. Udani J.K., Singh B.B., Barrett M.L. et al. Proprietary arabinogalactan extract increases antibody response to the pneumonia vaccine: a randomized, doubleblind, placebo-controlled, pilot study in healthy volunteers. Nutrition Journal. 2010, vol. 9, p.32.

21. Chistyachenko Y.S.,. Dushkin A.V, Polyakov N.E. et al. Polysaccharide arabinogalactan from larch Larix sibirica as carrier for molecules of salicylic and acetylsalicylic acid: Preparation, physicochemical and pharmacological study. Drug Delivery. 2015, vol. 22, pp. 400-407. 
22. Mikhailenko M., Shakhtshneider T., Eltsov I.V. et al. Supramolecular architecture of betulin diacetate complexes with arabinogalactan from Larix sibirica. Carbohydrate Polymers. 2016, vol. 138, pp. 1-7.

23. Shakhtshneider T., Mikhailenko M., Kuznetsova S. et al. New derivatives of betulin esters with arabinogalactan as highly potent anticancer agents. Natural Product Res. 2016, vol. 30, pp.1382-87.

24. Showalter A.M., Keppler B., Lichtenberg J.et al. A bioinformatics approach to the identification, classification, and analysis of hydroxyproline-rich glycoproteins. Plant Physiol. 2010, vol. 153, pp. 485-513.

\title{
PRUNUS DOMESTICA (ALBALI) TORKIBINDD OSAS POLISAXARIDLORIN QURULUŞ VO XASSOLORININ TODQIQI
}

\author{
Ş.Z. Tapdıqov, N.A. Zeynalov, D.B. Tă̆ıyev, Ü.M. Ohmədova \\ A.İ. Mommadova, M.X. Hosonova, M.A. Omirov
}

Azərbaycan Milli Elmlər Akademiyası akad. M. Nağıyev adına Kataliz və Qeyri-üzvi Kimya İnstitutu Bakl, AZ1143, H.Cavid pr.113,E-mail: shamo.chem.az@gmail.com

Araşdırma albalı ăgacından əldə edilən selik ekzudatının durulaşdırllmış sulu məhlulunun FTIR və

${ }^{13} \mathrm{C} N M R$ spektroskopiya, termo-gravimetrik, radioaktiv va viskozimetrik analizlarina hosr olunmuşdur. Müəyyən olunmuşdur ki, Azərbaycanın Şamaxı arazisindəki albalı kitrasi ekstraktının asas tərkibi qalaktan va arabinan qalıqlarından ibaratdir və tərkibində 14\% nəm, 2-3\% miqdarında is mineral duzlar saxlayır. Bunlardan üstünlük taşkil edəni $\mathrm{Na}^{+}, \mathrm{Mg}^{2+}, \mathrm{Ca}^{2+}, \mathrm{K}^{+}, \mathrm{Zn}^{2+}, \mathrm{Fe}^{3+}$ ionlarl, $\mathrm{Cu}^{2+}, \mathrm{Mn}^{2+}, \mathrm{Pb}^{2+}, \mathrm{Cd}^{2+}$ ionlart isa ümumi kütlada $0.001 \%$ tartibda olur. NMR va FT-IR analizlarina asasən tərkibdə $-\mathrm{OH},-\mathrm{COOH},-\mathrm{O}$ - funksional qrupları müşahidə edilmiş və arabinoqalaktan fraksiyasının molekul kütlasinin $130 \mathrm{kDa}$ olduğu tayin edilmişdir. Hamçinin albalı kamedinin torkibindəki ${ }^{137} \mathrm{Cs},{ }^{226} \mathrm{Ra},{ }^{228} \mathrm{Ra},{ }^{40} \mathrm{~K},{ }^{235} \mathrm{U},{ }^{238} \mathrm{U}$ kimi radioaktiv elementlorin miqdarl va aktivliyi $\gamma$ spektrometri ila müəyyən edilmişdir. Sübut olunmuşdur ki, tarkibdə ${ }^{238} U$ və ${ }^{40} \mathrm{~K}$ izotoplarl üstünlük təşkil edir vo uyğun olaraq $1.31 \pm 0.243$ vo $04 \pm 0.16 \mathrm{Bk} / \mathrm{qr}$ taşkil edir. Kamedin bela radioaktiv izotopları özündo toplaması galacəkdə arabinoqalaktan tərkibdə sobentlorin hazırlanmasina asas verir.

Açar sözlor: polisaxarid, albalı kitrasi, arabinoqalaktan, NMR və IQ spektroskopiya, radioaktiv izotop

\section{ИССЛЕДОВАНИЕ СОСТАВА И СВОЙСТВ ОСНОВНЫХ ПОЛИСАХАРИДОВ PRUNUS DOMESTICA (ВИШНЯ)}

\author{
ШІ.З. Тапдыгов, Н.А. Зейналов, Д.Б. Тагиев, У.М. Ахмедова, \\ А.И. Маммедова, М.Х. Гасанова, М.А. Амиров
}

\begin{abstract}
Институт Катализа и Неорганической Химии им. акад. М. Нагиева Национальной АН Азербайджана,

AZ 1143 Баку, пр.Г.Джавида, 113; e-mail:shamo.chem.az@gmail.com
\end{abstract}

Исследование посвящено ИК $и{ }^{13}$ С ЯМР спектроскопическому, термогравиметрическому, радиоактивному и визкозиметрическому анализам разбавленного экзудата водного раствора слизи, полученному из вишневого дерева. Установлено что в окрестностях города Шамахи (Азербайджан) в составе экстракта вишневой камеди в основном остатке имеется галактан и арабинан, влажность составляет $14 \%$ и в количестве 2-3\% содержатся минеральные соли. Большинство из них составляют $\mathrm{Na}^{2+} \mathrm{Mg}^{2+}, \mathrm{Ca}^{2+}, \mathrm{K}^{+}, \mathrm{Zn}^{2+}, \mathrm{Fe}^{3+}$ ионы. Ионы $\mathrm{Cu}^{2+}, \mathrm{Mg}^{2+}, \mathrm{Cd}^{2+}$ содержатся в основном составе в количестве 0.001\%. По анализам 
ЯМР и ИК спектроскопии в основном составе наблюдаются -OH, -COOH, -Oфункииональные группы и молекулярная масса для фракиии арабиногалактана определена в количестве $130 \kappa \mathrm{\kappa}$. Также в составе вишневой камеди методом $\gamma$-спектроскопии установлены количество $и$ активность радиоактивных элементов ${ }^{137} \mathrm{Cs},{ }^{226} \mathrm{Ra},{ }^{228} \mathrm{Ra},{ }^{40} \mathrm{~K},{ }^{235} \mathrm{U},{ }^{238} \mathrm{U}$. Доказано, что в составе изотопь ${ }^{238} \mathrm{U},{ }^{40} \mathrm{~K}$ составляют большинство и активности их равны соответственно $1.31 \pm 0.243$ и $0.4 \pm 0.16$ Bк/2. Содержание в составе камеди таких радиоактивных изотопов дает возможность в будущем готовить сорбенты, имеющие в составе арабиногалактаны.

Ключевые слова: полисахариды, вишневая камедь, арабиногалактан, ЯМР и ИК спектроскопия, радиоактивный изотоп

Received 26.12.2017. 